\author{
R.Kh. Dzhanabekova, M.S.Kim, N.Kh. Ibrayev \\ Institute of Molecular Nanophotonics, Ye.A. Buketov Karaganda State University, Kazakhstan \\ (E-mail: rumiya_j@mail.ru)
}

\title{
Detection of polycyclic aromatic hydrocarbons by surface enhanced Raman scattering on colloidal silver substrates
}

\begin{abstract}
The present work reports on the possibility of polycyclic aromatic hydrocarbons (PAHs) detection by surface enhanced Raman scattering (SERS) on substrates coated with colloidal silver stabilized with cetyltrimethylammonium bromide (CTAB). It was shown that cetyltrimethylammonium bromide acts not only as a stabilizer of metal nanoparticles, but also as modifying agent that promotes the concentration of hydrophobic PAH molecules near the amplified electromagnetic field of plasmon silver nanoparticles. Anthracene and pyrene were used as model analytes. To determine the sensitivity of the prepared SERS active coating, ethanol solutions of the analyzed substances with concentrations in the range of $2 \cdot 10^{-4}-10^{-6}$ $\mathrm{mol} / \mathrm{L}$ were used. The lowest concentrations of solutions for which anthracene and pyrene are found on the tested substrates were equal to $2.5 \cdot 10^{-6} \mathrm{M}$ and $5 \cdot 10^{-5} \mathrm{M}$, respectively. These results indicate that substrates are more sensitive to anthracene than to pyrene. The work also shows that various PAH molecules can be detected by characteristic peaks in a complex mixture without preliminary separation of the components.
\end{abstract}

Keywords: surface-enhanced Raman scattering, polycyclic aromatic hydrocarbons, anthracene, pyrene, silver nanoparticles, cetyltrimethylammonium bromide, SERS sensor, plasmon particles.

\section{Introduction}

Polycyclic aromatic hydrocarbons (PAHs) are strong environmental pollutants. PAHs are mainly formed and evolved during oil refining, mineral oil and coal combustion. In addition, PAHs are formed during smoking, during high-temperature processing of food products. Most organic pollutants have carcinogenic and mutagenic properties. Although PAHs are released into the environment in relatively small quantities, they are quite resistant to external influences and can accumulate in soil and water to dangerous concentrations [1-3].

Currently, chromatographic methods, such as liquid chromatography with fluorescence methods and gas chromatography in combination with mass spectroscopy, are used to detect PAHs [1-4]. Chromatography methods have high sensitivity and reproducibility, however, the analysis requires long and complex sample preparation.

A promising alternative to chromatographic methods for PAHs deterction is surface-enhanced Raman spectroscopy (SERS). SERS is based on a giant amplification of the electromagnetic field induced by noble metal nanoparticles as a result of plasmon resonance. An increase in the electromagnetic field at distances up to several tens of nanometers from nanoparticles significantly increases the changes in the polarization of the electron cloud and, therefore, the Raman signal [5-7]. The work of [8] demonstrated that the maximum gain can reach values of $10^{10}-10^{11}$. The maximum signal amplification is facilitated by a combination of longrange electromagnetic and short-range chemical amplifications $[5,6,9]$.

It is well known [9] that SERS active molecules usually exhibit good affinity for metals, which leads to their approaching to the surface. And most of the currently available developments and commercial SERS sensors are focused precisely on such analytes. At the same time, there are a number of organic compounds containing hydrophobic molecules with low affinity for metals that not adsorbed on the active surface of «traditional» SERS substrates and cannot be determined by this method. PAHs belong to this category of unconventional analytes.

Recently, researchers have made significant efforts to develop methods to facilitate the use of SERS in the detection of unconventional analytes. For these purposes, metal nanostructures are modified with substances that promote the adsorption of hydrophobic molecules near the plasmonic nanoparticles. Alkylthiols [10, 11], calixarenes [12, 13], and cyclodextrins [14, 15] are quite successfully used as modifiers.

In the present work, the possibility of using silver nanoparticles (Ag NPs) in the complex with cetyltrimethylammonium bromide (CTAB) for the determination of PAHs by the SERS method was studied. $\mathrm{CTAB}$ is a cationic surfactant that is often used for the controlled synthesis of silver and gold nanoparticles 
as a stabilizing agent [16-18]. At the same time, CTAB was used to modify plasmon nanoparticles to determine PAHs only in very few studies $[19,20]$.

A feature of the presented work is the use of a simple, one-step method for producing Ag NPs stabilized by CTAB as a SERS sensor for detection individual and mixed PAHs.

\section{Experimental}

Synthesis of colloidal silver particles. Silver nanoparticles were obtained by the reduction of silver nitrate with sodium borohydride. Cetyltrimethylammonium bromide was used to stabilize the nanoparticles. The preparation of silver nanoparticles was performed according to the technique proposed in [18]. The synthesis was carried out in a $50 \mathrm{ml}$ beaker, with continuous sonication. CTAB $(0.22 \mathrm{~g})$ and silver nitrate $(0.085 \mathrm{~g})$ were successively dissolved in $10 \mathrm{ml}$ of deionized water. After 10 minutes of sonication, $2.5 \mathrm{ml}$ of a freshly prepared sodium borohydride solution $(0.04 \mathrm{~g})$ was droped. After the addition of the reducing agent, the solution was kept in an ultrasonic bath for another 20 minutes.

Preparation of analyte solutions. Anthracene and pyrene were used as model PAHs. Stock solutions of anthracene and pyrene in ethanol with a concentration of $10^{-3} \mathrm{~mol} / \mathrm{L}$ were prepared. The studied solutions with PAH concentrations in the range of $2 \cdot 10^{-4}-10^{-6} \mathrm{~mol} / \mathrm{L}$ were prepared immediately before measurements by successive dilution of the stock solution.

Preparation of SERS-active substrates. Silica glasses were used as the basis for SERS-active substrates. $15 \mu \mathrm{l}$ of silver hydrosol was deposited on glass and distributed over the surface with a glass rod. The prepared film was dried at room temperature in air.

Measurements. The absorption spectrum of the synthesized silver hydrosol was measured on a Cary 300 spectrophotometer (Agilent). The sizes of the nanoparticles were determined by dynamic light scattering using the Zetasizer NanoS (Malvern) system. To measure the absorption spectrum and sizes of Ag NPs, the initial solution was previously diluted 150 times.

The Raman spectra of the samples were measured on a Confotec MR 520 scanning laser Raman spectrometer. A laser with $\lambda=532 \mathrm{~nm}$ radiation was used to excite Raman spectra. The laser power on the sample was $2.2 \mathrm{~mW}$, and the spectral accumulation time was $10 \mathrm{~s}$. To measure the Raman spectra, $5 \mu \mathrm{l}$ of the corresponding PAH solution were dropped onto the surface of the prepared substrates; the drop was dried under natural conditions. Spectra were recorded on each sample from 7 points; the obtained data were averaged. For more convenient visualization, the spectra in the presented graphs are spaced relative to each other.

\section{Results and discussion}

Silver nanoparticles obtained by the borohydride method in the presence of CTAB form stable aquasols [18]. The absorption spectrum of the synthesized aquazole in the visible region with a maximum at $417 \mathrm{~nm}$ (Figure 1) indicates the formation of plasmon silver nanoparticles [21]. The study of Ag NPs by the method of dynamic light scattering showed the presence in the solution of particles ranging in size from 1 to $18 \mathrm{~nm}$.

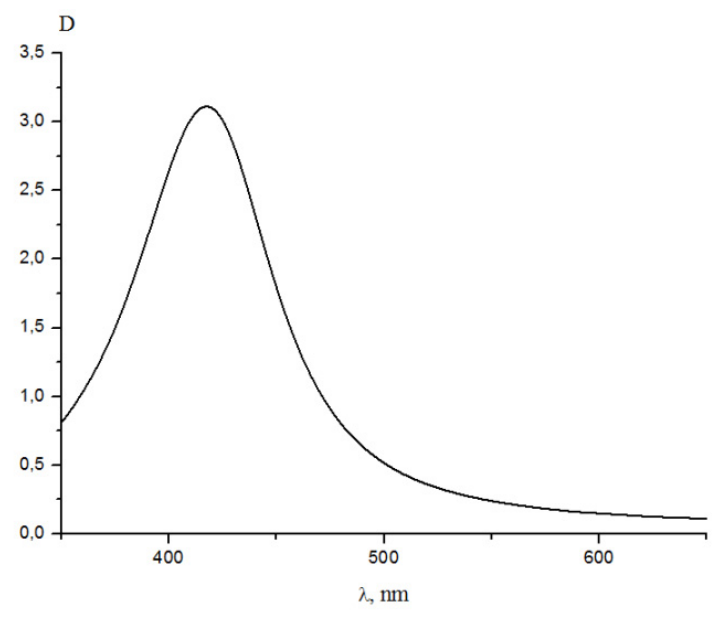

Figure 1. Absorption spectrum of Ag NPs solution 
$\mathrm{CTAB}$ is a cationic surfactant that, on the one hand, plays the role of a stabilizer to prevent aggregation of silver nanoparticles. On the other hand, the presence of a long hydrocarbon tail contributes to the solubilization of hydrophobic molecules, as a result of which PAH molecules are concentrated and held near metal nanoparticles. Thus, the analyte molecules find themselves in the zone of the amplified electromagnetic field of the plasmon particles.

Figure 2 shows the Raman spectrum of crystalline anthracene and the SERS spectra of the substrate (AgNPs - CTAB) and $2 \cdot 10^{-4} \mathrm{M}$ anthracene solution on the substrate.

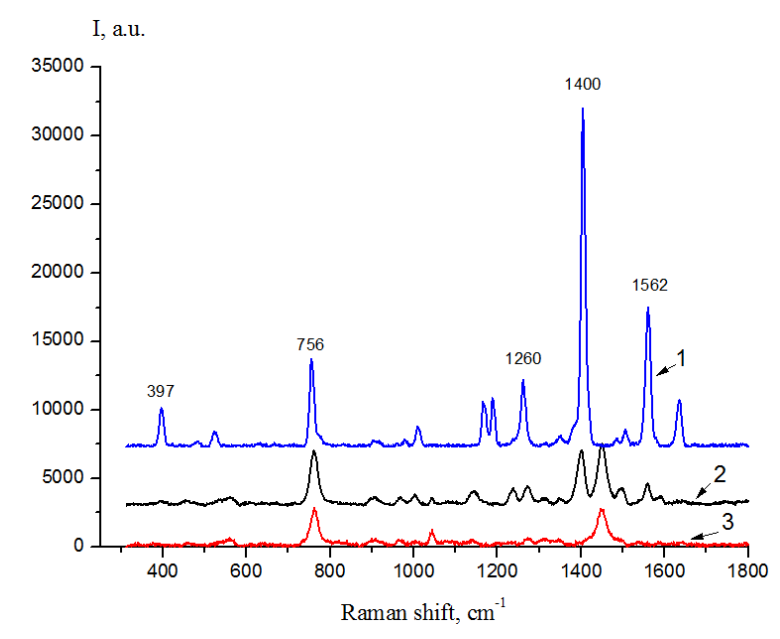

Figure 2. Raman spectrum of crystalline anthracene (1), SERS spectra of the $2 \cdot 10^{-4} \mathrm{M}$ anthracene solution on the substrate (2) and the substrate (3)

The SERS spectrum of the substrate is characterized by two main Raman bands at 760 and $1450 \mathrm{~cm}^{-1}$, which belong to the CTAB [19, 20]. The obtained Raman spectrum of crystalline anthracene has characteristic bands of medium and high intensity at 397, 756, 1260,1400, and $1562 \mathrm{~cm}^{-1}$. In the SERS spectrum of $2 \cdot 10^{-4} \mathrm{M}$ anthracene solution on the substrate, bands belonging to both anthracene $(397,1260,1400$ and $\left.1562 \mathrm{~cm}^{-1}\right)$ and CTAB $\left(760,1450 \mathrm{~cm}^{-1}\right)$ are clearly observed. The Raman band of anthracene at $756 \mathrm{~cm}^{-1}$ coincides with the CTAB Raman band at $760 \mathrm{~cm}^{-1}$ and cannot be used for analytical purposes.

The SERS spectrum obtained for $2 \cdot 10^{-4} \mathrm{M}$ pyrene solution on the substrate is shown in Figure 3 . The Raman spectrum of crystalline pyrene and the SERS spectrum of the substrate are also presented for comparison. The Raman spectrum of crystalline pyrene is characterized by frequency shifts at 406, 594, 1242, 1408, 1597 , and $1630 \mathrm{~cm}^{-1}$. In the SERS spectra of the pyrene solution, the bands at 406, 1242, 1408, 1597, and $1630 \mathrm{~cm}^{-1}$, which belong to the pyrene, and the bands at 760 and $1450 \mathrm{~cm}^{-1}$, which belong to the substrate, are most clearly observed.

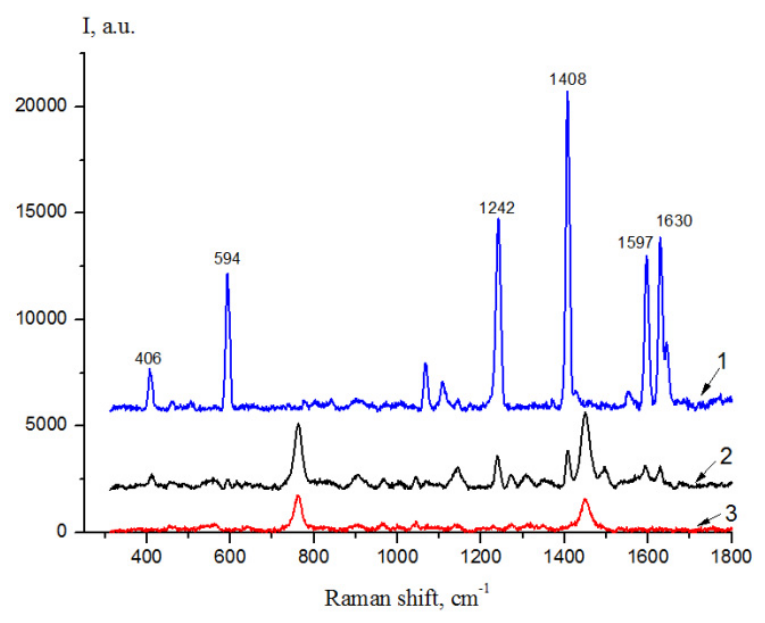

Figure 3. Raman spectrum of crystalline pyrene (1), SERS spectra of the $2 \cdot 10^{-4} \mathrm{M}$ pyrene solution on the substrate (2) and the substrate (3) 
To determine the minimum concentration of PAHs on the test coating, we measured the SERS spectra of solutions in the concentration range of $2 \cdot 10^{-4}-10^{-6} \mathrm{~mol} / \mathrm{L}$. SERS spectra of anthracene and pyrene with different concentrations are shown in Figures 4 and 5.

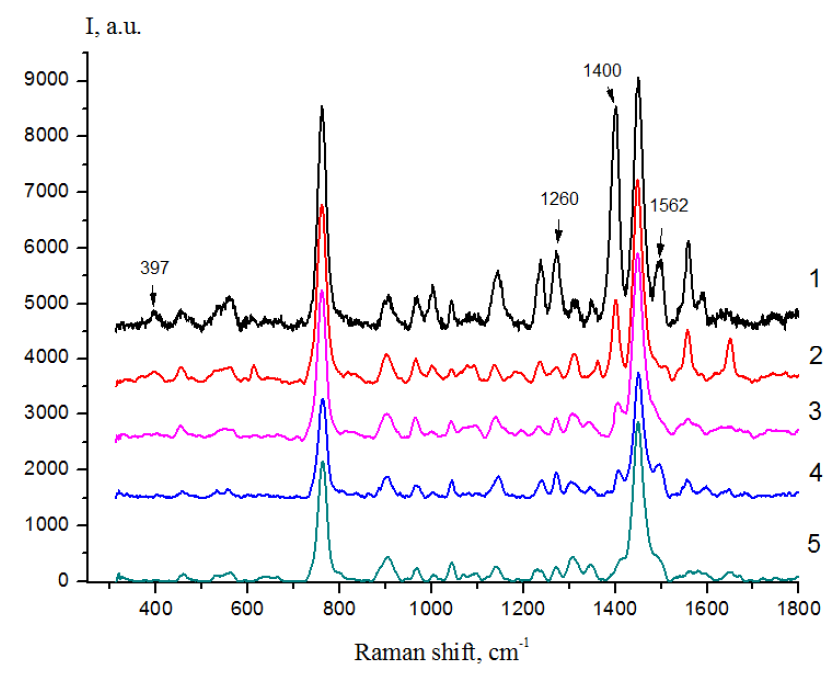

Figure 4. SERS spectra of anthracene solutions with different concentration, $\mathrm{mol} / \mathrm{L}$ :

$$
1-2 \cdot 10^{-4}, 2-5 \cdot 10^{-5}, 3-5 \cdot 10^{-6}, 4-2.5 \cdot 10^{-6}, 5-10^{-6}
$$

To determine the content of anthracene, an intense Raman scattering band at $1400 \mathrm{~cm}^{-1}$ was used. As can be seen from Figure 4, this band is clearly observed in the SERS spectra of anthracene for solutions of $2 \cdot 10^{-4}-2.5 \cdot 10^{-6} \mathrm{~mol} / \mathrm{L}$. In the SERS spectrum of anthracene with a concentration of $10^{-6} \mathrm{~mol} / \mathrm{L}$, the characteristic band at $1400 \mathrm{~cm}^{-1}$ is practically not detected. Thus, $2.5 \cdot 10^{-6} \mathrm{~mol} / \mathrm{L}$ is the lowest concentration of the solution in which anthracene is found on the tested substrates.

Figure 5 shows the SERS spectra of different concentrations of pyrene. To detect pyrene, several Raman bands can be used as analytical: at $1242,1408,1597$, and $1630 \mathrm{~cm}^{-1}$. It can be seen from the obtained spectra that for solutions with concentration of $5 \cdot 10^{-6} \mathrm{~mol} / \mathrm{L}$ and lower, characteristic peaks of pyrene are practically not detected. The minimum detectable pyrene concentration in the solution was $5 \cdot 10^{-5} \mathrm{~mol} / \mathrm{L}$.

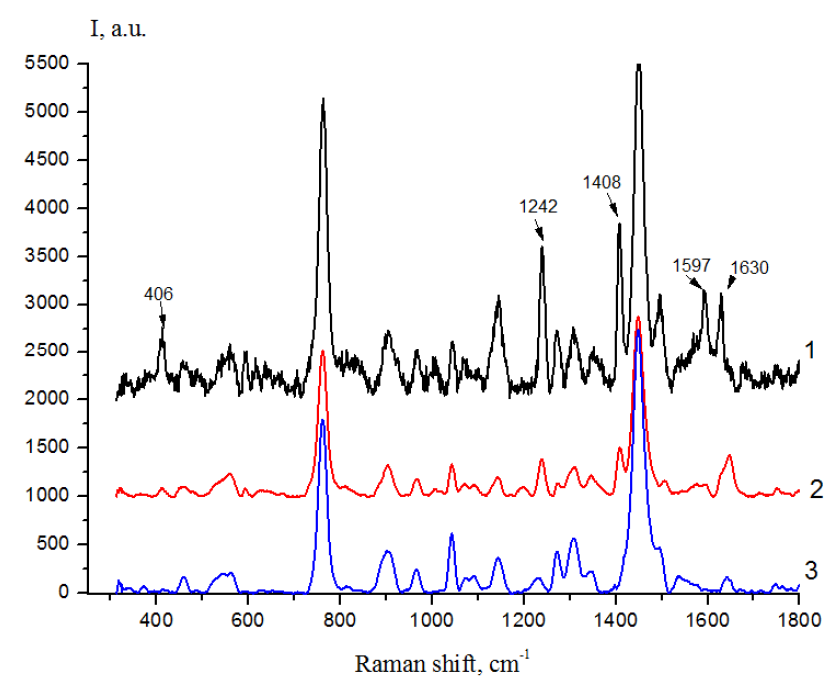

Figure 5. SERS spectra of pyrene solutions with different concentration, $\mathrm{mol} / \mathrm{L}$ :

$$
1-2 \cdot 10^{-4}, 2-5 \cdot 10^{-5}, 3-5 \cdot 10^{-6}
$$

The results obtained indicate that the coating based on Ag NPs with CTAB is more sensitive to anthracene. 
The identification of PAHs was also carried out in a complex system that simultaneously contains anthracene and pyrene. Figure 6 presents the SERS spectrum obtained for solution containing $10^{-4} \mathrm{~mol} / \mathrm{L}$ anthracene and $10^{-4} \mathrm{~mol} / \mathrm{L}$ pyrene.

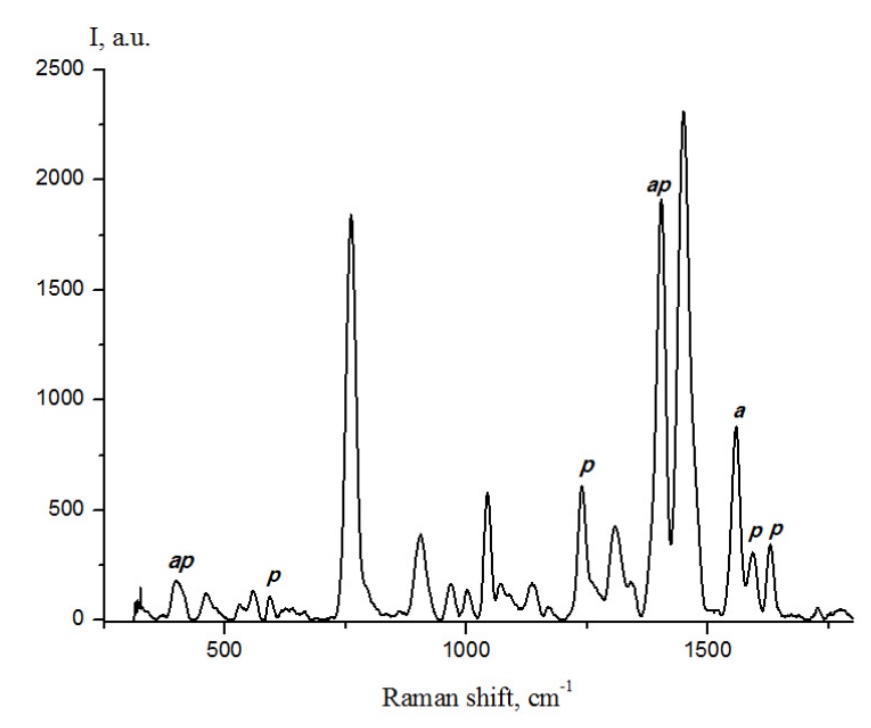

Figure 6. SERS spectrum of mixed solution of anthracene and pyrene

The anthracene bands in the figure are indicated by the letter $\boldsymbol{a}$, and the pyrene bands are indicated by the letter $\boldsymbol{p}$. The anthracene bands at 397 and $1400 \mathrm{~cm}^{-1}$ overlap with the pyrene bands at 406 and $1408 \mathrm{~cm}^{-1}$ and, therefore, cannot be used for identification in this mixture. However, the main peaks of individual PAHs are well distinguishable. Thus, the tested SERS coating can be used to identify PAHs in complex systems without prior separation of components.

\section{Conclusion}

It was shown that colloidal silver nanoparticles stabilized by CTAB can be used to obtain the SERS active substrate. In the resulting system, CTAB acts not only a stabilizer of silver nanoparticles, but also a modifier that promotes the concentration and holding of PAH molecules near the surface of plasmon particles. The maximum concentration of solutions in which anthracene and pyrene were detected are equal to $2.5 \cdot 10^{-6} \mathrm{M}$ and $5 \cdot 10^{-5} \mathrm{M}$, respectively. With further optimization, the prepared substrates can be used as sensors both in determining individual PAHs and in the simultaneous detection of individual components in complex mixtures.

This work was carried out as part of the research project BR05236691, funded by the Ministry of Education and Science of the Republic of Kazakhstan.

\section{References}

1 Другов Ю.С. Экологическая аналитическая химия / Ю.С. Другов. - М.: Москва, 2000. — 432 с.

2 Другов Ю.С. Методы анализа загрязнений воздуха / Ю.С. Другов, А.В. Беликов, Г.А. Дьякова, В.М. Тульчинский. М.: Химия, 1984. - 384 с.

3 Plaza-Bolanos P. Polycyclic aromatic hydrocarbons in food and beverages. Analytical methods and trends / P. Plaza-Bolanos, A.G. Frenich, J.L.M. Vidal // J. Chromatogr. A. — 2010. — Vol. 1217. — P. 6303-6326.

4 Moret S. Polycyclic aromatic hydrocarbons in edible fats and oils: occurrence and analytical methods. / S. Moret, L.S. Conte // J. Chromatogr. A - 2000. - Vol. 882. - P. 245-253.

5 Moskovits M. Surface-enhanced spectroscopy / M. Moskovits // Rev. Mod. Phys. — 1985. — Vol. 57. — P. $783-826$.

6 Etchegoin L.R., Principles of Surface-Enhanced Raman Spectroscopy and Related Plasmonic Effects / L.R. Etchegoin. Amsterdam: Elsevier Science, 2008. - 633 p.

7 Гигантское комбинационное рассеяние / под ред. Р. Ченга, Т. Фуртака. - М.: Мир, 1984. — 408 с. 
8 Etchegoin P.G. A perspective on single molecule SERS: current status and future challenges / P.G. Etchegoin, E.C. Le Ru // Phys. Chem. Chem. Phys. - 2008. — Vol. 10. - P. 6079-6089.

9 Поверхностно-усиленная рамановская спектроскопия (SERS): аналитические, биофизические и биомедицинские приложения / под ред. С.М. Шлюкера. - М.: Техносфера, 2017. - 328 с.

$10 \mathrm{Gu}$ X. SERS detection of polycyclic aromatic hydrocarbons on a bowl-shaped silver cavity substrate / X. Gu, Sh. Tian, Q. Zhou, J. Adkins, Zh. Gu, X. Li et al. // RSC Adv. — 2013. - Vol. 3. - P. 25989-25996.

11 Jones C.L. Partition layer-modified substrates for reversible surface-enhanced Raman scattering detection of polycyclic aromatic hydrocarbons / C.L. Jones, K.C. Bantz, C.L. Haynes // Anal. Bioanal. Chem. - 2009. - Vol. 394. - P. $303-311$.

12 Guerrini L. Functionalization of Ag Nanoparticles with Dithiocarbamate Calix [4] arene As an Effective Supramolecular Host for the Surface-Enhanced Raman Scattering Detection of Polycyclic Aromatic Hydrocarbons / L. Guerrini, J.V. Garcia-Ramos, C. Domingo, S. Sanchez-Cortes // Langmuir. - 2006. - Vol. 22. - P. 10924-10926.

13 Shi X. Trace analysis of polycyclic aromatic hydrocarbons using calixarene layered gold colloid film as substrates for surface - enhanced Raman scattering / X. Shi, Y.-H. Kwon, J.Ma, R. Zheng, C. Wang, H.D. Kronfeldt // J. Raman Spectrosc. 2013. - Vol. 44. - P. 41-46.

14 Xie Y. Sensing of polycyclic aromatic hydrocarbons with cyclodextrin inclusion complexes on silver nanoparticles by surface-enhanced Raman scattering / Y. Xie, X. Wang, X. Han, X. Xue, W. Ji, Z. Qi et al. // Analyst. — 2010. — Vol. 135. - P. 13891394.

15 Xie Y. Selective SERS detection of each polycyclic aromatic hydrocarbon (PAH) in a mixture of five kinds of PAHs. / Y. Xie, X. Wang, X. Han, W. Song, W. Ruan, J. Liu, B. Zhao, Y. Ozaki // J. Raman Spectrosc. — 2011, Vol. 42. — P. $945-950$.

16 Богатырев В.А. Методы синтеза наночастиц с плазмонным резонансом: учеб. пос. / В.А. Богатырев, Л.А. Дымкан, Н.Г. Хлебцов. - Саратов: СГУ им. Н.Г.Чернышевского, $2009-35$ с.

17 Бегунов И.Б. Получение наностержней серебра методом контролируемого роста на ядрах кристаллизации / И.Б. Бегунов, М.Ю. Королева, Е.В. Юртов // Успехи в химии и хим. технологии. — 2014. — Т. 28, № 6. — С. $37-39$.

18 Васильева С.Ю. Сорбционное концентрирование пирена наночастицами серебра и его люминесцентное определение в водных растворах / С.Ю. Васильева, А.Ю. Оленин, Г.И. Романовская, Ю.А. Крутяков, В.И. Погонин, А.С. Коротков и др. // Журн. аналит. хим. - 2009. — Т. 64, № 12. — С. 1244-1250.

19 Jiang M. CTAB micelles assisted rGO-AgNP hybrids for SERS detection of polycyclic aromatic hydrocarbons / M. Jiang, Zh. Qian, X. Zhou, X. Xin, J. Wu, Ch. Chen et al. // Phys. Chem. Chem. Phys. - 2015. - Vol. 17. - P. 21158-21163.

20 Gao Y. CTAB-triggered Ag aggregates for reproducible SERS analysis of urinary polycyclic aromatic hydrocarbon metabolites / Y. Gao, L. Li, X. Zhang, X. Wang, W. Ji, J. Zhao et al. // Chem. Commun. - 2019. - Vol. 55. -P. $2146-2149$.

21 Evanoff D.D. Jr. Synthesis and optical properties of silver nanoparticles and arrays / D.D. Jr. Evanoff, G. Chumanov // Chem. Phys. Chem. - 2005. — Vol. 6, № 7. - P. 1221-1231.

\title{
P.Х. Джанабекова, М.С. Ким, Н.Х. Ибраев
}

\section{Коллоидты күміс төсеніштерінде полициклді хош иісті көмірсутектерді беті-күшейтілген комбинациондық шашырау әдісімен анықтау}

\begin{abstract}
Мақалада цетилтриметиламмоний бромидімен (ЦТАБ) тұрақтандырылған, коллоидтық күміспен қапталған төсеніштер бетінде полициклді хош иісті көмірсутектерді (ПХК) беті-күшейтілген комбинациондық шашырау (SERS) әдісімен анықтау мүмкіндігі туралы айтылған. Цетилтриметиламмоний бромиді металл нанобөлшектерін тұрақтандырушысы ғана емес, сонымен қатар плазмондық күміс нанобөлшектердің күшейтілген электромагниттік өрісінің жанында ПХК гидрофобты молекулаларының шоғырлануына ықпал ететін модификациялаушы зат рөлін атқаратындығы көрсетілген. Модель аналиттері ретінде антрацен мен пирен қолданылған. Дайындалған SERS-белсенді қабыршақтарының сезімталдығын анықтау үшін талданатын заттардың концентрациясы $2 \cdot 10^{-4}-10^{-6}$ моль/л диапазонындағы спирттік ерітінділері қолданылған. Алынған қабыршақтарда антрацен мен пирен ерітінділердің сигнал алған ең төменгі концентрациясы сәйкесінше $2,5 \cdot 10^{-6} \mathrm{M}$ және $5 \cdot 10^{-5} \mathrm{M}$ құрайды. Бұл нәтижелер қабыршақтардың пиренмен салыстырғанда антраценге сезімтал екенін көрсетеді. Сонымен қатар, жұмыста әртүрлі ПХК молекулаларын құрамдас бөліктерді алдын-ала бөлмей, күрделі қоспада өзіне тән шындарға сәйкес анықтауға болатындығы көрсетілген.
\end{abstract}

Кілт сөздер: беті-күшейтілген комбинациондық шашырау, полициклді хош иісті көмірсутектер, антрацен, пирен, күміс нанобөлшектері, цетилтриметиламмоний бромиді, SERS сенсоры, плазмондық нанобөлшектер. 


\title{
Р.Х. Джанабекова, М.С. Ким, Н.Х. Ибраев \\ Определение полициклических ароматических углеводородов методом поверхностно-усиленного комбинационного рассеяния на подложках коллоидного серебра
}

\begin{abstract}
В статье сообщается о возможности определения полициклических ароматических углеводородов (ПАУ) методом поверхностно-усиленного комбинационного рассеяния (SERS) на подложках, покрытых коллоидным серебром, стабилизированным цетилтриметиламмония бромидом (ЦТАБ). Показано, что цетилтриметиламмония бромид выполняет роль не только стабилизатора наночастиц металла, но и роль модифицирующего агента, способствующего концентрации гидрофобных молекул ПАУ вблизи усиленного электромагнитного поля плазмонных наночастиц серебра. В качестве модельных аналитов были использованы антрацен и пирен. Для определения чувствительности приготовленного SERS-активного покрытия использованы спиртовые растворы анализируемых веществ с концентрациями в диапазоне $2 \cdot 10^{-4}-10^{-6}$ моль/л. Наименьшие концентрации растворов, для которых на полученных подложках обнаруживаются антрацен и пирен, составляют $2,5 \cdot 10^{-6} \mathrm{M}$ и $5 \cdot 10^{-5} \mathrm{M}$ соответственно. Эти результаты указывают на то, что подложки более чувствительны к антрацену, чем к пирену. В работе также показано, что различные молекулы ПАУ могут быть обнаружены по характерным пикам в сложной смеси без предварительного разделения компонентов.
\end{abstract}

Ключевые слова: поверхностно-усиленное комбинационное рассеяние, полициклические ароматические углеводороды, антрацен, пирен, наночастицы серебра, цетилтриметиламмония бромид, SERS сенсор, плазмонные частицы.

\section{References}

1 Drugov, Yu.S. (2000). Ekolohicheskaia analiticheskaia khimiia [Ecological analytical chemistry]. Moscow: Moskva [in Russian].

2 Drugov, Yu.S., Belikov, A.V., Diakova, G.A., \& Tulchinskii, V.M. (1984). Metody analiza zahriaznenii vozdukha [Air pollution analysis methods]. Moscow: Khimiia [in Russian].

3 Plaza-Bolanos, P., Frenich, A.G., \& Vidal, J.L.M. (2010). Polycyclic aromatic hydrocarbons in food and beverages. Analytical methods and trends. J. Chromatogr. A, 1217, 6303-6326.

4 Moret, S., \& Conte, L.S. (2000). Polycyclic aromatic hydrocarbons in edible fats and oils: occurrence and analytical methods. J. Chromatogr. A., 882, 245-253.

5 Moskovits, M. (1985). Surface-enhanced spectroscopy. Rev. Mod. Phys., 57, 783-826.

6 Etchegoin, L. R. (2008). Principles of Surface-Enhanced Raman Spectroscopy and Related Plasmonic Effects. Amsterdam: Elsevier Science.

7 Chang, R., \& Furtak, T. (Eds.). (1984). Hihantskoe kombinatzionnoe rasseianie [Surface Enhanced Raman Scattering]. Moscow: Mir [in Russian].

8 Etchegoin, P.G., \& Le Ru, E.C. (2008). A perspective on single molecule SERS: current status and future challenges. Phys. Chem. Chem. Phys., 10, 6079-6089.

9 Shliuker, S.M. (Eds.). (2017). Poverkhnostno-usilennaia ramanovskaia spektroskopiia (SERS): analiticheskie, biofizicheckie i biomeditsinskie prilozheniia [Surface-enhanced Raman spectroscopy (SERS): analysis, biophysical and biomedical applications]. Moscow: Technosphera [in Russian].

10 Gu, X,. Tian, Sh., Zhou, Q., Adkins, J., Gu, Zh., \& Li, X., et al. (2013). SERS detection of polycyclic aromatic hydrocarbons on a bowl-shaped silver cavity substrate. RSC Adv., 3, 25989-25996.

11 Jones, C.L., Bantz, K.C., \& Haynes, C.L. (2009). Partition layer-modified substrates for reversible surface-enhanced Raman scattering detection of polycyclic aromatic hydrocarbons. Anal. Bioanal. Chem., 394, 303-311.

12 Guerrini, L., Garcia-Ramos, J.V., Domingo, C., \& Sanchez-Cortes, S. (2006). Functionalization of Ag Nanoparticles with Dithiocarbamate Calix [4] arene As an Effective Supramolecular Host for the Surface-Enhanced Raman Scattering Detection of Polycyclic Aromatic Hydrocarbons. Langmuir, 22, 10924-10926.

13 Shi, X., Kwon, Y.-H., Ma, J., Zheng, R., Wang, C., \& Kronfeldt, H.D. (2013). Trace analysis of polycyclic aromatic hydrocarbons using calixarene layered gold colloid film as substrates for surface-enhanced Raman scattering. J. Raman Spectrosc., 44, 4146.

14 Xie, Y., Wang, X., Han, X., Xue, X., Ji, W., \& Qi, Z., et al. (2010). Sensing of polycyclic aromatic hydrocarbons with cyclodextrin inclusion complexes on silver nanoparticles by surface-enhanced Raman scattering. Analyst., 135, $1389-1394$.

15 Xie, Y., Wang, X., Han, X., Song, W., Ruan, W., \& Liu, J., et al. (2011). Selective SERS detection of each polycyclic aromatic hydrocarbon (PAH) in a mixture of five kinds of PAHs. J. Raman Spectrosc., 42, 945-950.

16 Bogatyrev, V.A., Dymkan, L.A., \& Khlebszov, N.G. (2009). Metody sinteza nanochastits s plazmonnym rezonansom [Synthesis methods for plasmon resonance nanoparticles]. Saratov: SGU [in Russian].

17 Begunov, I.B., Koroleva, M.Yu., \& Yurtov, E.V. (2014). Polucheniie nanosterzhnei serebra metodom kontroliruiemoho rosta na yadrakh kristsllizatsii [Preparation of silver nanorods by controlled growth method on crystallization nuclei]. Uspekhi khimii $i$ khimicheskoi tekhnolohii, 28, 6, 37-39 [in Russian]. 
18 Vasilyeva, S.Yu., Olenin, A.Yu., Romanovskaya, G.I., Krutyakov, Yu.A., Pogonin, V.I., \& Korotkov, A.S., et al. (2009). Sorbtsionnoe kontzentrirovanie pirena i eho liuminestzentnoe opredelenie v vodnykh rastvorakh [Sorption concentration of pyrene by silver nanoparticles and its luminescent determination in aqueous solutions]. Zhurnal analiticheskoi khimii, 64, 12, 1244-1250 [in Russian].

19 Jiang, M., Qian, Zh., Zhou, X., Xin, X., Wu, J., \& Chen, Ch., et al. (2015). CTAB micelles assisted rGO-AgNP hybrids for SERS detection of polycyclic aromatic hydrocarbons. Phys. Chem. Chem. Phys., 17, 21158-21163.

20 Gao, Y., Li, L., Zhang, X., Wang, X., Ji, W., \& Zhao, J., et al. (2019). CTAB-triggered Ag aggregates for reproducible SERS analysis of urinary polycyclic aromatic hydrocarbon metabolites. Chem. Commun., 55, 2146-2149.

21 Evanoff, D.D. Jr., \& Chumanov, G. (2005). Synthesis and optical properties of silver nanoparticles and arrays. Chem. Phys. Chem., 7, 1221-1231. 